\title{
JPSE
}

(Journal of Physical Science and Engineering)

Received
28 May 2021
Revised
17 July 2021
Accepted for Publication
29 September 2021
Published
12 October 2021

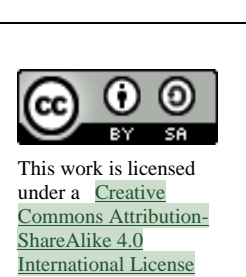

\section{Identification of Elemental Composition and Heavy Metal Content in Maninjau Lake Sediment Using X-Ray Fluorescence (MNJ 18-41B)}

\author{
F Akmal ${ }^{1 *}$, H Rifai ${ }^{1}$, Syafriani ${ }^{1}$, C B De La Maisonneauve ${ }^{2}$, J A G Oalmann ${ }^{2}$, \\ F Forni $^{2}$, S Eisele ${ }^{2}$, M Phua ${ }^{2}$, and R Putra ${ }^{3}$ \\ 1. Department of Physics, Faculty of Mathematics and Natural Sciences, Universitas Negeri Padang, \\ Jl. Prof. Dr. Hamka, Padang, 25173, Indonesia. \\ 2. Asian School of the Environment, Nanyang Technological University, 50 Nanyang Avenue, \\ 639798, Singapore. \\ 3. Bayerisches Geoinstitut, Universität Bayreuth, Universitätsstr 30 Bayreuth, 95440, Germany. \\ *E-mail: fajarakmal12@gmail.com
}

\begin{abstract}
Maninjau Lake is a caldera lake located in Agam, West Sumatra. This lake was formed from the volcanic activity of Mount Maninjau Purba about 60,000 years ago. The volcanic material resulting from the eruption is scattered and deposited in various places, one of which is in lake sediments. Volcanic ash contains various types of elements, including heavy metal elements. This study aims to determine the composition and content of heavy metal in the sediments of Maninjau Lake. The sample analyzed was MNJ 18-41B with a core length of $440 \mathrm{~mm}$, focusing on specimens $148 \mathrm{~mm}$ and $376 \mathrm{~mm}$. The selection is a specimen based on the magnetic susceptibility value obtained from the measurement meter susceptibility of the MS2E. Specimen 148 has a value susceptibility low of $2.1 \times 10^{-8} \mathrm{~m}^{3} / \mathrm{kg}$, while the 376 specimens have the highest value of susceptibility, the highest $141 \times 10^{-8} \mathrm{~m}^{3} / \mathrm{kg}$. The content of sediment elements was determined using the results of X-Ray Fluorescence (XRF) measurements. The measurement results showed that the mineral-forming elements in the sediments of Lake Maninjau were dominated by $\mathrm{Si}, \mathrm{Fe}, \mathrm{Rh}$, and $\mathrm{Zr}$. In contrast, the highest heavy metal elements are $\mathrm{Mn}, \mathrm{Fe}, \mathrm{Sr}$, and $\mathrm{Rh}$. Based on the elemental composition and mineral oxide compounds in the sediments of Lake Maninjau derived from volcanic ash.

Keywords: Sediment, heavy metals, XRF, susceptibility.
\end{abstract}

\section{Introduction}

Lake Maninjau is a caldera type lake located in Agam, West Sumatra [1], [2]. The surface area of Maninjau Lake is $97.9 \mathrm{~km}^{2}$, at an altitude of 459 meters [3]. Based on the bathymetry, Maninjau Lake has an average depth of 100 meters. This lake was formed from the volcanic activity of Mount Maninjau Purba, which erupted about 60,000 years ago. The eruption ejected volcanic material that travelled up to 75 kilometres from the epicentre. Volcanic material settles in various places such as in peatlands, rivers, and seas. Eighty-eight rivers empty into the lake, so many materials are transported, one of which is volcanic material [1]. This is what contributes to the presence of volcanic material in lake sediments.

Sediments are particles resulting from weathering of rocks, biological materials, chemical deposits, dust, plant residue materials, and leaves deposited on a medium [4]. Sediment is formed through a sedimentation process. Sedimentation is a process of deposition of solids in liquids due to the force of gravity [5]. Sediment at the lake's bottom accumulates from various sources, such as river flows [6]. The material at the lake's bottom can also come from volcanic activity, such as volcanic ash carried by the wind, which is then deposited on riverbeds. Volcanic material or tephra undergoes a process of transportation to various places. Four characteristics need to be observed to describe the sediment, i.e. the sediment's colour, structure, texture, and composition [7]. Volcanic eruptions generally contain oxides of several hazardous metal elements such as aluminium (Al), silicon ( $\mathrm{Si}$ ), iron ( $\mathrm{Fe}$ ), calcium $(\mathrm{Ca})$, magnesium $(\mathrm{Mg})$, potassium $(\mathrm{K})$, sodium $(\mathrm{Na})$, sulfur $(\mathrm{S})$, and several dangerous heavy metal elements such as lead $(\mathrm{Pb})$, cadmium $(\mathrm{Cd})$, and arsenic (As) [8]. These elements will combine with other elements and will form minerals in lake sediments. 
Minerals are natural compounds formed through geological processes, while magnetic minerals are a collection of compounds with high magnetic properties [9]. The presence of magnetic minerals can determine the mineral content source in the lake's sediment deposits [10], [11]. Minerals in lake sediments can come from the deposition of volcanic ash from the atmosphere [12], river flow that empties into lakes [13], minerals from human activities [14], and autogenic processes [6]. Magnetic minerals have properties including diamagnetic, paramagnetic, ferromagnetic, and ferrimagnetic [15], [16]. The magnetic properties of a rock depend on the magnetic mineral carrying its magnetic properties, i.e. type, number, shape, and size of the magnetic mineral grains. The magnetic properties of rocks in their application to climate and environmental changes can be seen from these four factors. For example, magnetic minerals in sediment or soil are related to heavy metal elements in environmental studies. Thus, magnetic properties can be used to detect the presence of heavy metal elements in sediments [17].

Heavy metals have a specific gravity of more than $5 \mathrm{grams} / \mathrm{cm}^{3}$ with atomic numbers 22 to 92 [18]. Elements classified as heavy metals include As, copper (Cu), terbium (Tb), Al, zinc ( $\mathrm{Zn})$, nickel $(\mathrm{Ni})$, mercury $(\mathrm{Hg})$, and $\mathrm{Cd}$. Heavy metal contamination is hazardous for the environment because heavy metals cannot be decomposed (non-degradable) by organisms [19]. The presence of heavy metals that exceed the threshold level in waters is hazardous and will affect water quality [20]. One of the impacts of heavy metals on the waters is that they can result in mass fish mortality. The phenomenon of fish mortality that occurred in 2010-2014 was 2,100 tons. In addition, Lake Maninjau has an essential role for the surrounding community, such as hydropower, tourism activities, conservation, and fisheries [21]. So, it is necessary to identify the heavy metal content in the sediments of Lake Maninjau. The XRay Fluorescence (XRF) method can be used to identify heavy metal elements in Lake Maninjau sediments. The XRF method is one of the methods used to determine the chemical composition of a mineral, including powder, soil, liquid, or other forms [9], [22], [23].

\section{Method}

\section{1. $\quad$ Sampling}

Sampling was conducted in 2018 at coordinate $0^{\circ} 18^{\prime} 20.20^{\prime \prime S}$ and $100^{\circ} 12^{\prime} 31.36^{\prime \prime} \mathrm{E}$ in Agam District, West Sumatra, as shown in Figure 1. The samples taken were Lake Maninjau sediments. Sampling was conducted using a gravity core with a length of 1 meter, which was equipped with a deep PVC pipe to collect sediment samples. The gravity core is dropped vertically into the lake sediment so that the sediment enters the PVC pipe. In order to obtain a deeper sediment sample, the gravity core was weighted from the surface so that it could no longer add depth. Following that, the Gravity core is lifted

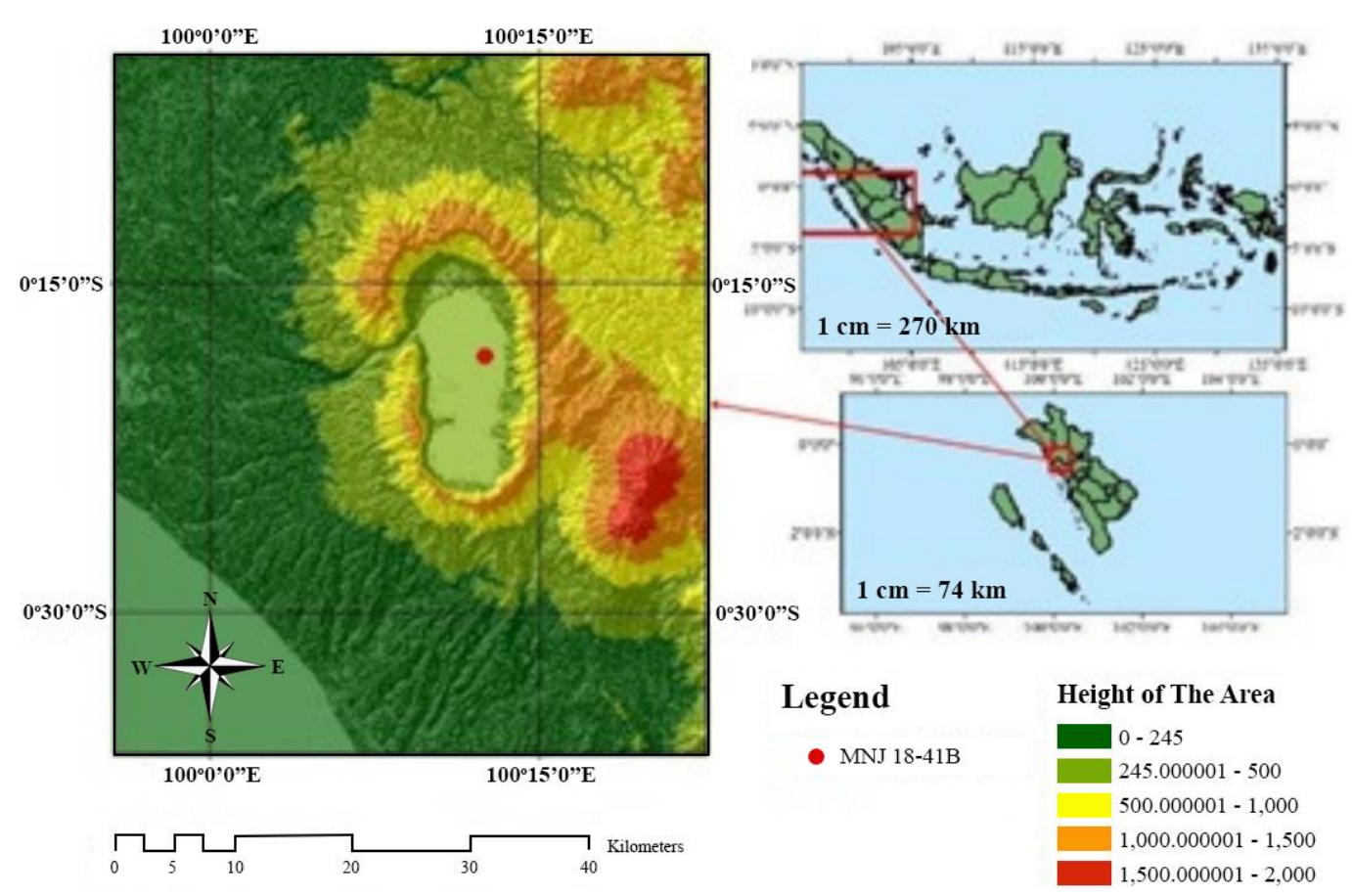

Figure 1. Sampling location in Lake Maninjau. 
and closes the top and bottom of the PVC pipe, preventing the sample from escaping. Researchers gave PVC pipe containing sediment the name and position mark of the sample. The sample must be vertical because if it changes, it will damage the structure and position of the sediment in the PVC pipe. After the sampling process is complete, the sample is stored in a cupboard or cold room to maintain the structure and position of the sample. The sample will shrink and dry out if it is left in an open room. The samples were stored until the preparation was carried out.

\subsection{Sample Preparation}

Preparation begins with the activity of splitting the PVC pipe into two parts using a splitting machine. The results of the splitting of the sample are shown in Figure 2. The sample used is MNJ 18-41B. After splitting, one part of the sample is stored back in the cold room and another part will be measured. Before measuring the sample's surface, it must be levelled first because the measurement stage uses a sensor that is sensitive to the sample surface.

\subsection{Sample Measurement}

The measurements made consisted of two stages. The first stage is the measurement of magnetic susceptibility using the susceptibility meter type MS2E. The results of magnetic susceptibility measurements are used for the selection of specimens to be identified. The second stage measures the concentration of elements in the sample using XRF with the type Avaatech XRF Scanner. The XRF measurement results obtained the element concentration per $2 \mathrm{~mm}$ of the total sample length of 440 $\mathrm{mm}$. In this study, two specimens were selected to be identified based on the highest and lowest susceptibility values. The identified specimens were at a depth of $148 \mathrm{~mm}$ and $376 \mathrm{~mm}$. Specimens 148 $\mathrm{mm}$ have the lowest susceptibility value of $2.1 \times 10^{-8} \mathrm{~m}^{3} / \mathrm{kg}$, while the $376 \mathrm{~mm}$ specimens have the highest susceptibility value of $141 \times 10^{-8} \mathrm{~m}^{3} / \mathrm{kg}$.

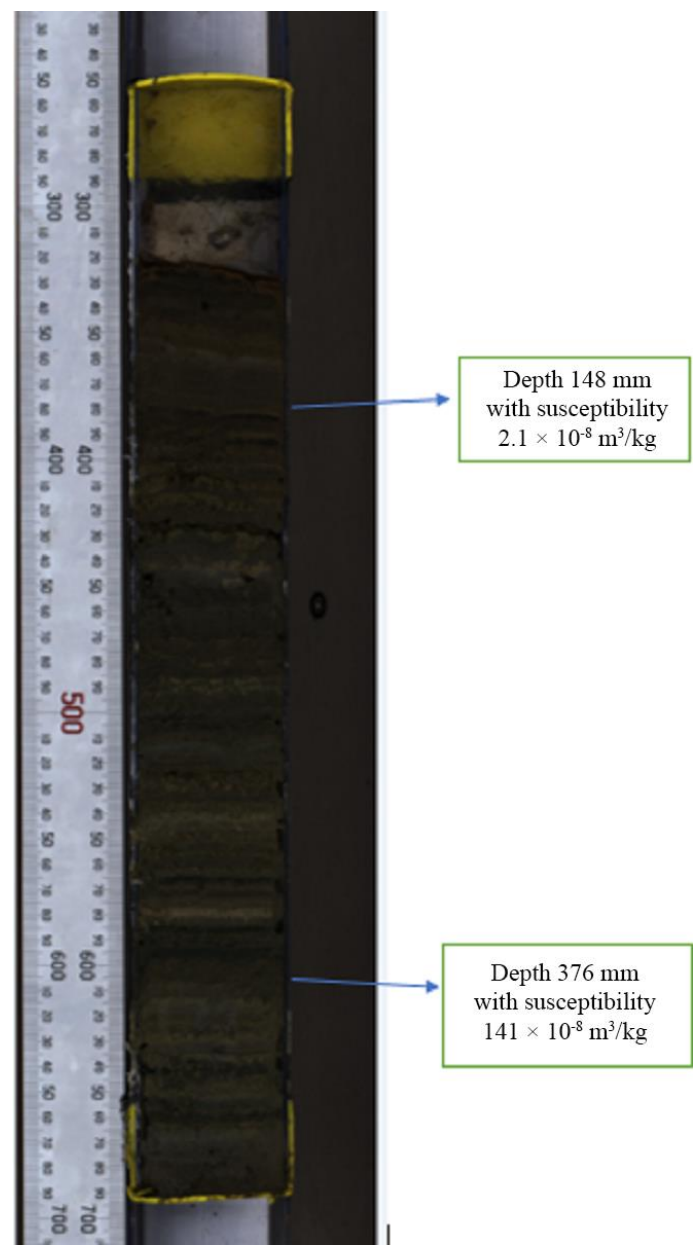

Figure 2. Lake Maninjau sediment (MNJ 18-41B). 
Table 1. Composition elements and oxides in depth $148 \mathrm{~mm}\left(2.1 \times 10^{-8} \mathrm{~m}^{3} / \mathrm{kg}\right)$.

\begin{tabular}{|c|c|c|c|c|}
\hline Elemental & Area (c/s) & Concentration (\%) & Oxide & Concentration (\%) \\
\hline Aluminum $(\mathrm{Al})$ & 598 & 0.255 & $\mathrm{Al}_{2} \mathrm{O}_{3}$ & 0.667 \\
\hline Silicone $(\mathrm{Si})$ & 14,869 & 6.342 & $\mathrm{SiO}_{2}$ & 18.122 \\
\hline Phosphor $(\mathrm{P})$ & 4 & 0.002 & $\mathrm{P}_{2} \mathrm{O}_{5}$ & 0.006 \\
\hline Sulfur (S) & 722 & 0.308 & $\mathrm{SO}_{2}$ & 0.827 \\
\hline Chlorine $(\mathrm{Cl})$ & 6,009 & 2.563 & $\mathrm{Cl}_{2} \mathrm{O}$ & 4.182 \\
\hline Potassium (K) & 1,912 & 0.815 & $\mathrm{~K}_{2} \mathrm{O}$ & 1.320 \\
\hline Calcium $(\mathrm{Ca})$ & 5,120 & 2.184 & $\mathrm{CaO}$ & 4.070 \\
\hline Titanium (Ti) & 3,306 & 1.410 & $\mathrm{TiO}_{2}$ & 3.134 \\
\hline Chrome (Cr) & 1,007 & 0.429 & $\mathrm{Cr}_{2} \mathrm{O}_{3}$ & 0.837 \\
\hline Manganese (Mn) & 1,779 & 0.759 & $\mathrm{MnO}$ & 1.307 \\
\hline Iron $(\mathrm{Fe})$ & 43,201 & 18.426 & $\mathrm{FeO}$ & 31.596 \\
\hline Rhodium (Rh) & 51,746 & 22.070 & - & - \\
\hline Vanadium $(\mathrm{V})$ & 464 & 0.198 & $\mathrm{~V}_{2} \mathrm{O}_{5}$ & 0.471 \\
\hline Cobalt (Co) & 7,695 & 3.282 & $\mathrm{CoO}$ & 5.561 \\
\hline Nickel (Ni) & 1,488 & 0.635 & Nio & 1.068 \\
\hline Copper $(\mathrm{Cu})$ & 4,597 & 1.961 & $\mathrm{CuO}$ & 3.267 \\
\hline Zinc (Zn) & 9,523 & 4.062 & $\mathrm{ZnO}$ & 6.747 \\
\hline Gallium $(\mathrm{Ga})$ & 453 & 0.193 & - & - \\
\hline Bromine $(\mathrm{Br})$ & 10,523 & 4.488 & - & - \\
\hline Rubidium (Rb) & 13,278 & 5.663 & - & - \\
\hline Strontium $(\mathrm{Sr})$ & 17,996 & 7.675 & $\mathrm{SrO}$ & 12.095 \\
\hline Litrium $(\mathrm{Y})$ & 10,644 & 4.540 & - & - \\
\hline Zircon $(\mathrm{Zr})$ & 19,866 & 8.473 & - & - \\
\hline Lead $(\mathrm{Pb})$ & 6,377 & 2.720 & $\mathrm{PbO}$ & 3.907 \\
\hline Bismuth (Bi) & 1,285 & 0.548 & $\mathrm{Bi}_{2} \mathrm{O}_{3}$ & 0.817 \\
\hline Total & & 100.000 & & 100.000 \\
\hline
\end{tabular}

Table 2. Composition elements and oxides in depth $376 \mathrm{~mm}\left(141 \times 10^{-8} \mathrm{~m}^{3} / \mathrm{kg}\right)$.

\begin{tabular}{|c|c|c|c|c|}
\hline Elemental & Area (c/s) & Concentration (\%) & Oxide & Concentration (\%) \\
\hline Aluminum $(\mathrm{Al})$ & 803 & 0.375 & $\mathrm{Al}_{2} \mathrm{O}_{3}$ & 0.793 \\
\hline Silicone (Si) & 18,781 & 8.762 & $\mathrm{SiO}_{2}$ & 21.269 \\
\hline Phosphor (P) & 78 & 0.036 & $\mathrm{P}_{2} \mathrm{O}_{5}$ & 0.102 \\
\hline Sulfur (S) & 1,096 & 0.511 & $\mathrm{SO}_{2}$ & 1.156 \\
\hline Chlorine $(\mathrm{Cl})$ & 4,476 & 2.088 & $\mathrm{Cl}_{2} \mathrm{O}$ & 2.901 \\
\hline Potassium $(\mathrm{K})$ & 2,225 & 1.038 & $\mathrm{~K}_{2} \mathrm{O}$ & 1.416 \\
\hline Calcium $(\mathrm{Ca})$ & 5,114 & 2.386 & $\mathrm{CaO}$ & 3.792 \\
\hline Titanium (Ti) & 5,153 & 2.404 & $\mathrm{TiO}_{2}$ & 4.533 \\
\hline Chrome (Cr) & 1,060 & 0.495 & $\mathrm{Cr}_{2} \mathrm{O}_{3}$ & 0.811 \\
\hline Manganese (Mn) & 11,390 & 5.314 & $\mathrm{MnO}$ & 7.767 \\
\hline Iron $(\mathrm{Fe})$ & 47,046 & 21.948 & $\mathrm{FeO}$ & 31.977 \\
\hline Rhodium (Rh) & 46,212 & 21.559 & - & - \\
\hline Vanadium $(\mathrm{V})$ & 321 & 0.150 & $\mathrm{~V}_{2} \mathrm{O}_{5}$ & 0.304 \\
\hline Cobalt (Co) & 5,609 & 2.617 & $\mathrm{CoO}$ & 3.773 \\
\hline Nickel (Ni) & 1,583 & 0.739 & $\mathrm{NiO}$ & 1.065 \\
\hline Copper $(\mathrm{Cu})$ & 4,432 & 2.068 & $\mathrm{CuO}$ & 2.935 \\
\hline Zinc (Zn) & 4,920 & 2.295 & $\mathrm{ZnO}$ & 3248 \\
\hline Gallium (Ga) & 540 & 0.252 & - & - \\
\hline Bromine $(\mathrm{Br})$ & 4,839 & 2.258 & - & - \\
\hline Rubidium (Rb) & 10,753 & 5.017 & - & - \\
\hline Strontium $(\mathrm{Sr})$ & 12,877 & 6.007 & $\mathrm{SrO}$ & 8.048 \\
\hline Litrium (Y) & 6,815 & 3.179 & - & - \\
\hline Zircon $(\mathrm{Zr})$ & 11,049 & 5.155 & - & - \\
\hline Lead $(\mathrm{Pb})$ & 6,058 & 2.826 & $\mathrm{PbO}$ & 3.455 \\
\hline Bismuth (Bi) & 1,122 & 0.523 & $\mathrm{Bi}_{2} \mathrm{O}_{3}$ & 0.656 \\
\hline Total & & 100.000 & & 100.000 \\
\hline
\end{tabular}




\section{Result and Discussion}

The measurement uses X-Ray Fluorescence (XRF) of samples Lake Maninjau sediment MNJ 18-41B yields information about the concentration of elements in the sample. The measurement results are shown in Table 1 and Table 2.

\subsection{Elements Composition}

From Table 1 and Table 2, it can be seen that in the $148 \mathrm{~mm}$ specimen the element with the highest concentration was the Rh element, while in the $376 \mathrm{~mm}$ specimen it was the element Fe. To be more apparent, the comparison of the concentrations of each element at the two depths shown in Figure 3.

Based on Figure 3, the ratio of the element concentration of each specimen has different susceptibility values. The blue graph shows a $148 \mathrm{~mm}$ specimen with low susceptibility (2.6 SI), while the yellow one shows a $376 \mathrm{~mm}$ specimen with high susceptibility (141 SI). The dominant elements in Lake Maninjau sediment with a susceptibility value of $2.1 \mathrm{SI}$ (low susceptibility) are $\mathrm{Si}, \mathrm{Fe}, \mathrm{Rh}, \mathrm{Br}, \mathrm{Rb}$, $\mathrm{Sr}$, Y, and $\mathrm{Zr}$, with the highest concentration element is Rhodium (Rh) $22.07 \%$. In $376 \mathrm{~mm}$ specimen with $141 \mathrm{SI}$ susceptibility value (high susceptibility), the dominant elements are $\mathrm{Si}, \mathrm{Mn}, \mathrm{Fe}, \mathrm{Rh}, \mathrm{Rb}, \mathrm{Sr}$, and $\mathrm{Zr}$, with the highest concentration element is Iron $(\mathrm{Fe}) 21.56 \%$. Magnetic mineral-forming elements influenced the susceptibility value because specimens with high susceptibility values are indicated to have high magnetic mineral content [24], [25].

Magnetic minerals have the essential constituent elements of the fourth group transition group elements ( $\mathrm{Sc}, \mathrm{Ti}, \mathrm{V}, \mathrm{Cr}, \mathrm{Mn}, \mathrm{Fe}, \mathrm{Cn}, \mathrm{Bi}, \mathrm{Cu}$, and $\mathrm{Zn}$ ) [11], [25]. The magnetic mineral-forming elements found in this sample are $\mathrm{Ti}, \mathrm{V}, \mathrm{Cr}, \mathrm{Bi}, \mathrm{Cu}, \mathrm{Zn}, \mathrm{Fe}$, and $\mathrm{Mn}$. Examples of magnetic minerals of this element are $\mathrm{TiO}_{2}, \mathrm{~V}_{2} \mathrm{O}_{5}, \mathrm{Cr}_{2} \mathrm{O}_{5}, \mathrm{CuO}, \mathrm{ZnO}$, and $\mathrm{Fe}_{3} \mathrm{O}_{4}$. The elements forming magnetic minerals ( $\mathrm{Ti}, \mathrm{V}$, $\mathrm{Cr}, \mathrm{Cu}, \mathrm{Zn}, \mathrm{Fe}, \mathrm{Mn}$ ) have a higher concentration at a depth of $376 \mathrm{~mm}$ compared to a depth of $148 \mathrm{~mm}$. Meanwhile, the Bi element is higher at a depth of $148 \mathrm{~mm}$, but the difference is not very significant. These elements cause different susceptibility values, especially Fe [26]. Fe element has the highest magnetic susceptibility value and the magnetic property of the material is ferromagnetic. The relationship between the element $\mathrm{Fe}$ and its susceptibility is comparable. Because the $376 \mathrm{~mm}$ specimen contains a higher concentration of magnetic elements than the $148 \mathrm{~mm}$ specimen, it has a higher susceptibility value.

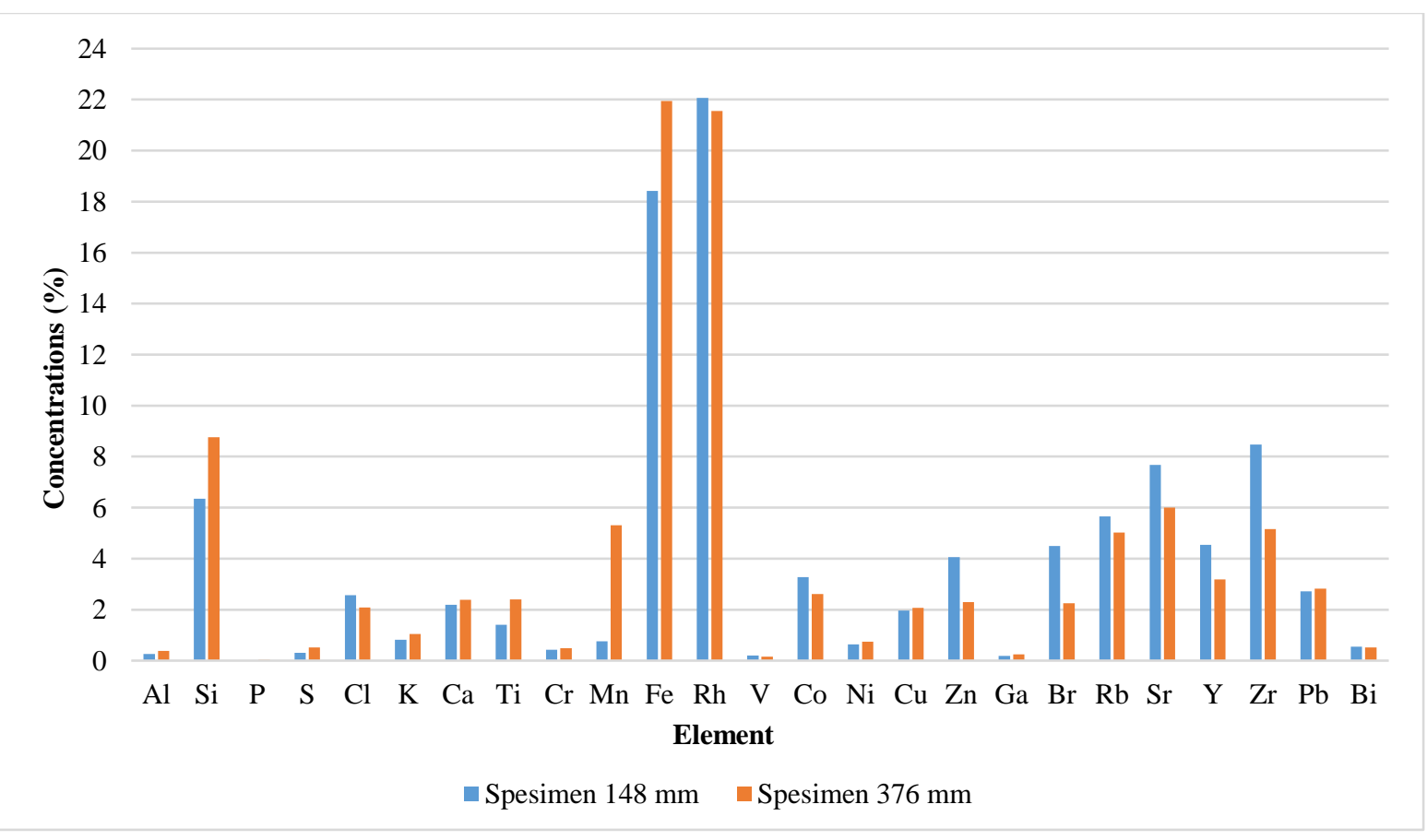

Figure 3. Comparison of the element concentration of MNJ 18-41B for $148 \mathrm{~mm}$ and $376 \mathrm{~mm}$ specimens. 


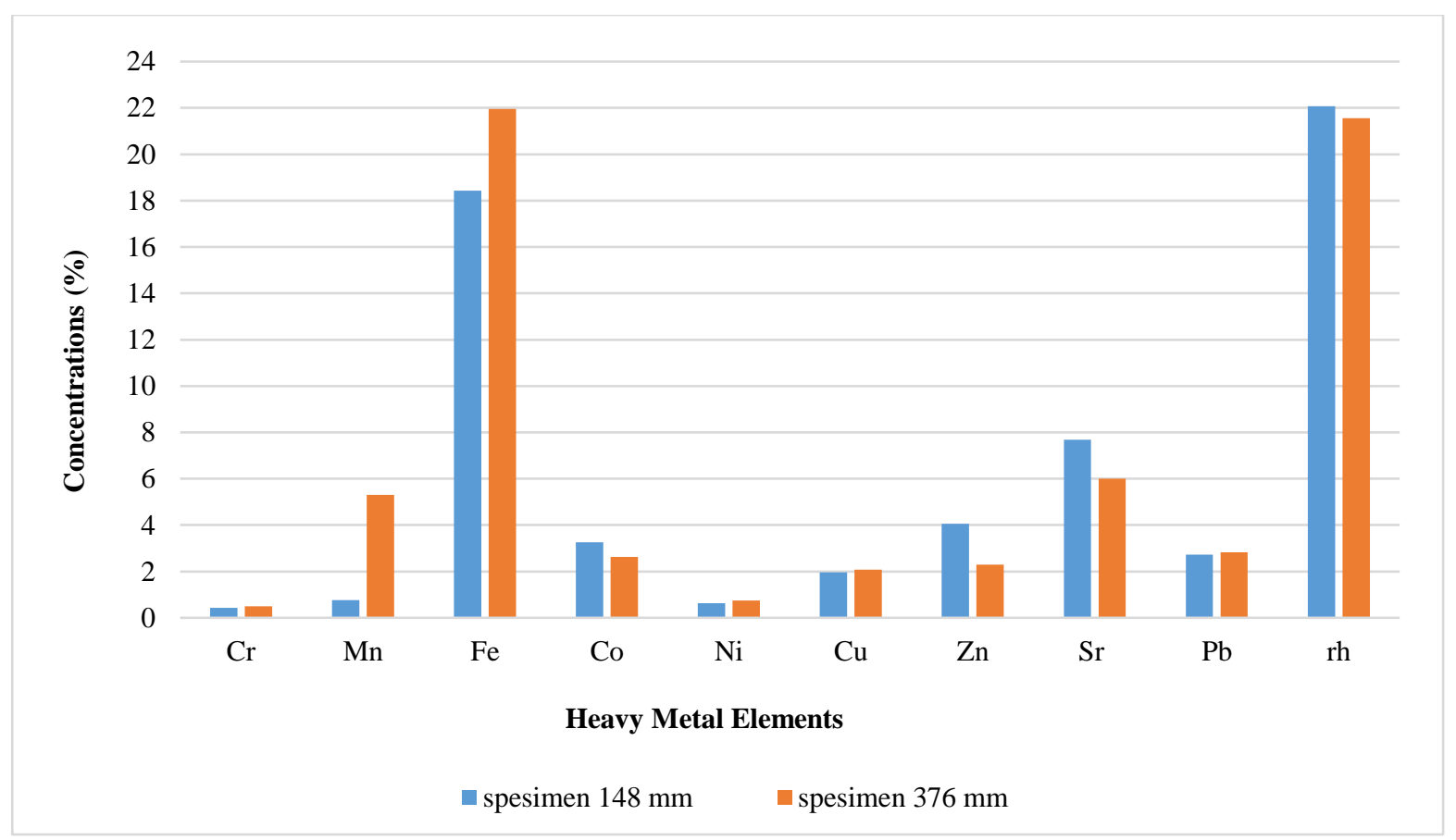

Figure 4. Comparison of the heavy metal element concentration of MNJ 18-41B for $148 \mathrm{~mm}$ and $376 \mathrm{~mm}$ specimens.

\subsection{Content of Heavy Metal Elements}

Heavy metal elements also affect magnetic susceptibility values. So, it is necessary to identify the content of heavy metal elements. The comparison of heavy metal concentrations in each specimen is shown in Figure 4. Both specimens have the same elemental content but different concentrations value. The highest metal element in the $148 \mathrm{~mm}$ specimen was the Rh element, with a concentration of $22.07 \%$. Meanwhile, in the $378 \mathrm{~mm}$ specimen was the Fe element, with a concentration of $21.95 \%$.

Heavy metal elements contained in this sample are $\mathrm{Cr}, \mathrm{Mn}, \mathrm{Fe}, \mathrm{Cu}, \mathrm{Zn}, \mathrm{Ni}, \mathrm{Sr}$, and $\mathrm{Pb}$. The concentration of heavy metals at each depth is different. At a depth of $148 \mathrm{~mm}$ specimen, the concentration of heavy metal elements $\mathrm{Co}, \mathrm{Sr}, \mathrm{Zn}$, and $\mathrm{Rh}$ were higher than at a depth of $378 \mathrm{~mm}$ specimen. The element Co (3.2\%) is ferromagnetic, $\mathrm{Sr}(7.68 \%)$ and $\mathrm{Rh}(22.07 \%)$ are paramagnetic, while $\mathrm{Zn}(4.06 \%)$ is diamagnetic. The highest heavy metal at a depth of $148 \mathrm{~mm}$ is Rhodium (Rh), which is paramagnetic. As a result, the susceptibility value of the specimen is low with many paramagnetic elements, whereas it is high with elements with low ferromagnetic properties. For a depth of $378 \mathrm{~mm}$ specimen, heavy metal elements are $\mathrm{Cr}, \mathrm{Cu}, \mathrm{Mn}, \mathrm{Ni}, \mathrm{Fe}$, and $\mathrm{Pb}$ have a higher concentration than the $148 \mathrm{~mm}$ specimen. The element $\mathrm{Cr}(0.49 \%), \mathrm{Ni}(0.74 \%)$, and $\mathrm{Fe}(21.95 \%$, which is the highest element in this specimen) are ferromagnetic, $\mathrm{Cu}(2.07 \%)$ and $\mathrm{Pb}(2.83 \%)$ are diamagnetic, while $\mathrm{Mn}$ $(5.31 \%)$ is paramagnetic [7].

Several factors influence the susceptibility value based on heavy metal element analysis. The first is the elemental content in the sample. Samples that contain high heavy metal elements will have a high sufficiency value. The second is the depth of the sample. The deeper the sample is from the surface, the higher the susceptibility value. This is because sediment is formed during the deposition process, so the surface sediment contains more impurities than the depth sediment. The variation in depth from the surface is directly proportional to the value of magnetic susceptibility [27]. These factors cause the susceptibility value of $376 \mathrm{~mm}$ specimen to be higher than $148 \mathrm{~mm}$ specimen.

\subsection{Content of Oxide}

Minerals are chemical compounds with composition within certain limits, which a formula can express. Mineral formulas can be simple or complex, depending on the number of elements present and the proportions of their combinations [28]. One type of mineral is an oxide compound. Oxides are chemical compounds that contain at least one oxygen atom and one other element [29]. 


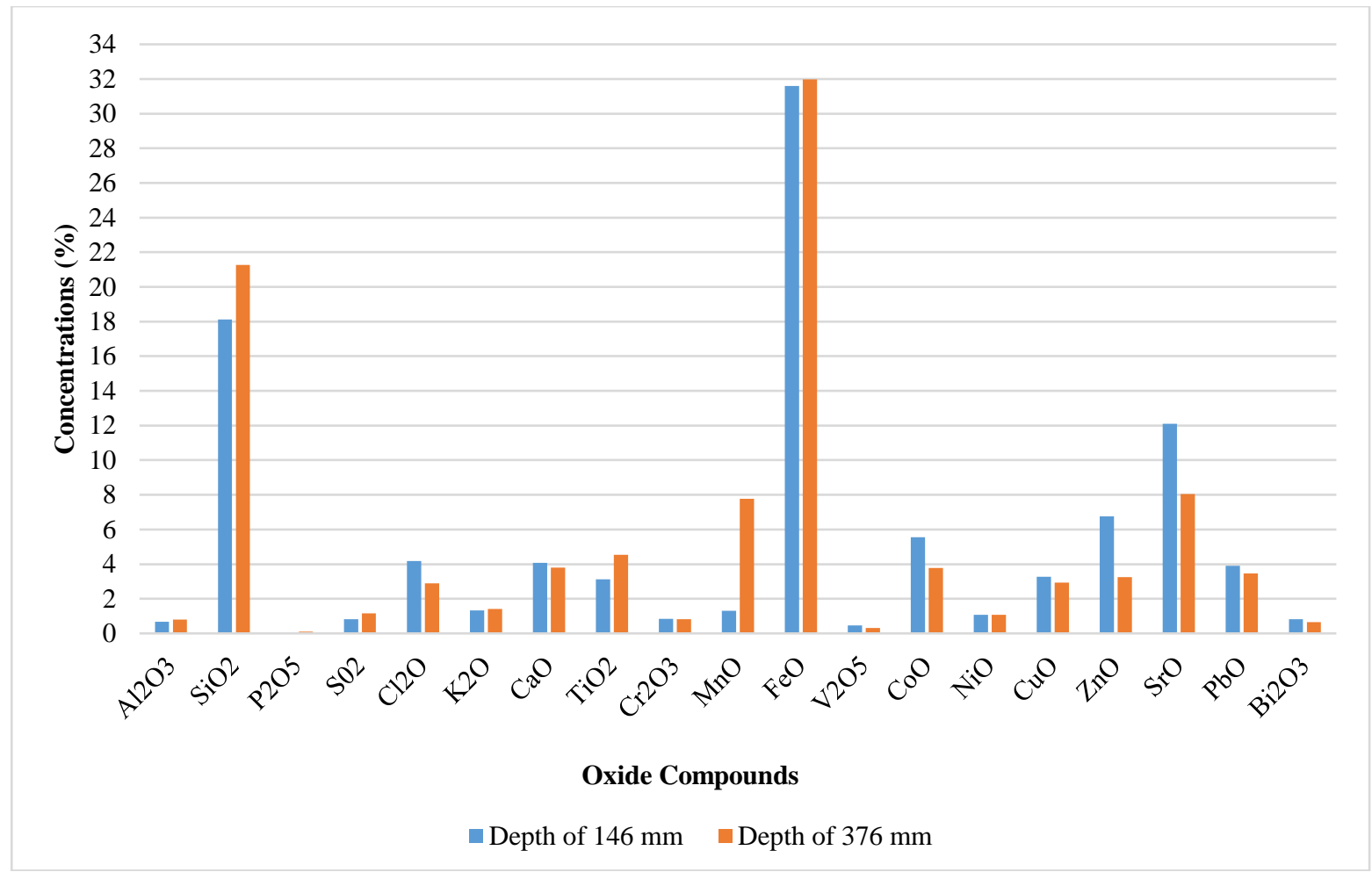

Figure 5. Comparison of the oxie compounds concentration of MNJ 18-41B for $148 \mathrm{~mm}$ and $376 \mathrm{~mm}$ specimens.

Some of the dominant oxide compounds in this study are $\mathrm{SiO}_{2}, \mathrm{FeO}, \mathrm{SrO}$, and $\mathrm{MnO}$. However, several elements cannot bind to oxygen from the elements obtained, namely $\mathrm{Rh}, \mathrm{Ga}, \mathrm{Br}, \mathrm{Rb}, \mathrm{Y}$, and $\mathrm{Zr}$. One of the reasons that some elements cannot be bonded is that they are precious metals that are difficult to oxidize [30]. The ratio of oxide concentrations in the two specimens can is shown in Figure 5. Based on the results of XRF measurements, Lake Maninjau sediment contains volcanic ash elements in $\mathrm{Al}, \mathrm{Si}$, $\mathrm{Ca}, \mathrm{Fe}, \mathrm{K}, \mathrm{Mn}, \mathrm{P}, \mathrm{S}$, and Ti. Because volcanic ash contains various major elements (Al, $\mathrm{Si}, \mathrm{Ca}$, and $\mathrm{Fe}$ ) and minor elements (K, Mg, Mn, Na, P, S, and Ti), so it can be said that nothing in the sediments of Lake Maninjau comes from various sources, one of which is volcanic activity.

\section{Conclusion}

Based on the results and discussion, it can be concluded that the mineral-forming elements in the sediments of Maninjau Lake with MNJ 18-41B samples are dominated by $\mathrm{Si}, \mathrm{Fe}, \mathrm{Rh}$, and $\mathrm{Zr}$. The heavy metal elements present in the sample are $\mathrm{Cr}, \mathrm{Mn}, \mathrm{Fe}, \mathrm{Co}, \mathrm{Ni}, \mathrm{Cu}, \mathrm{Zn}, \mathrm{Sr}$, and $\mathrm{Pb}$. The highest concentration of heavy metal elements is the Iron $(\mathrm{Fe})$. The higher the content of heavy metal elements, the higher the susceptibility value. Apart from heavy metals, susceptibility is influenced by depth. The relationship between susceptibility and depth is directly proportional. Along with heavy metal elements, volcanic ash is discovered. The elements of volcanic ash found in the sample are $\mathrm{Al}, \mathrm{Si}, \mathrm{Ca}, \mathrm{Fe}, \mathrm{K}, \mathrm{Mn}$, $\mathrm{P}, \mathrm{S}$, and Ti.

\section{Acknowledgment}

The authors acknowledge financial support from PNBP Universitas Negeri Padang with contract number 449/UN35.13/LT/2019.

\section{References}

[1] A. Nontji, Danau-Danau Alami Nusantara. Jakarta: Puslit Limnologi LIPI, 2017.

[2] C. B. De Maisonneuve et al., "Bathymetric survey of lakes Maninjau and Diatas (West Sumatra), and Lake Kerinci (Jambi)," J. Phys.: Conf. Ser., vol. 1185, no. 1, p. 012001, 2019, doi: 10.1088/1742-6596/1185/1/012001.

[3] P. Lehmusluoto et al., "National inventory of the major lakes and reservoirs in Indonesia," Expedition Indodanau, Helsinki, Finland, 1997. 
[4] K. O. Usman, "Analisis sedimentasi pada Muara Sungai Komering Kota Palembang," J. Tek. Sipil dan Lingkung., vol. 2, no. 2, pp. 209-215, 2014.

[5] D. L. Roessiana, S. Setiyadi, and B. H. Sandy, "Model persamaan faktor koreksi pada proses sedimentasi dalam keadaan free settling," J. Sains Teknol. Lingkung., vol. 6, no. 2, pp. 98-106, 2014, doi: 10.20885/jstl.vol6.iss2.art3.

[6] D. S. Haryati, S. Zulaikah, and N. Y. Daryanti, "Magnetic properties and magnetic minerals morphology of orchards soils Batu Malang," In IOP Conf. Ser.: Earth and Environ. Sci., vol. 311, no. 1, p. 012040, 2019, doi: 10.1088/1755-1315/311/1/012040.

[7] M. Bursik, "Tephra dispersal," Geol. Soc., Londong, Spec. Publ., vol. 145, pp. 115-144, 1998, doi: 10.1144/GSL.SP.1996.145.01.07.

[8] E. T. Wahyuni, S. Triyono, and S. Suherman, "Penentuan komposisi kimia abu vulkanik dari erupsi Gunung Merapi (determination of chemical composition of volcanic ash from Merapi Mt. eruption)," J. Mns. Ligkung., vol. 19, no. 2, pp. 150-159, 2012, doi: 10.22146/jml.18531.

[9] E. D. Ningsih et al., "Identification of magnetic mineral forming elements in peatland Alahan Panjang West Sumatra Indonesia, section DD REP B 693 using x-ray fluorescence," J. Phys.: Conf. Ser., vol. 1481, no. 1, p. 012018, 2020, doi: 10.1088/1742-6596/1481/1/012018.

[10] A. C. Da Silva, M. J. Dekkers, C. Mabille, and F. Boulvain, "Magnetic susceptibility and its relationship with paleoenvironments, diagenesis and remagnetization: Examples from the Devonian carbonates of Belgium," Stud. Geophys. Geod., vol. 56, no. 3, pp. 677-704, 2012, doi: 10.1007/s11200-011-9005-9.

[11] R. Putra, H. Rifai, and C. M. Wurster, "Relationship between magnetic susceptibility and elemental composition of guano from Solek Cave, West Sumatera," J. Phys.: Conf. Ser., vol. 1185, no. 1, 2019, doi: 10.1088/1742-6596/1185/1/012011.

[12] R. Barasa, A. Rauf, and M. Sembiring, "Dampak debu vulkanik letusan Gunung Sinabung terhadap kadar $\mathrm{Cu}, \mathrm{Pb}$, dan B tanah di Kabupaten Karo," J. Online Agroekoteknologi, vol. 1, no. 4, pp. 1288-1297, 2013.

[13] E. K. Huliselan and S. Bijaksana, "Identifikasi mineral magnetik pada Lindi (Leachate)," $J$. Geofis., vol. 2, pp. 8-13, 2007.

[14] M. Mariyanto et al., "Heavy metal contents and magnetic properties of surface sediments in volcanic and tropical environment from Brantas River, Jawa Timur Province, Indonesia," Sci. Total Environ., vol. 675, pp. 632-641, 2019, doi: 10.1016/j.scitotenv.2019.04.244.

[15] R. N. Fajri et al., "Analysis of magnetic properties rocks and soils around the Danau Diatas, West Sumatra," J. Phys.: Conf. Ser., vol. 1185, no. 1, p. 012024, 2019, doi: 10.1088/17426596/1185/1/012024.

[16] L. D. Nanda, F. Tan, and M. Noer, "Tingkat partisipasi masyarakat dalam program penyelamatan dan pengelolaan lingkungan berkelanjutan Danau Maninjau," J. Kebijakan Sos. Ekonom. Kelautan dan Perikanan, vol. 8, no. 2, pp. 105-115, 2019, doi: 10.15578/jksekp.v8i2.7432.

[17] S. Zulaikah, "Prospek dan manfaat kajian kemagnetan batuan pada perubahan iklim dan lingkungan,” J. Fis. Unnes, vol. 5, no. 1, pp. 1-6, 2015, doi: 10.15294/jf.v5i1.7364.

[18] S. S. Adji, D. Sunarsih, and S. Hamda, "Pencemaran logam berat dalam tanah dan tanaman serta upaya menguranginya," presented at the Seminar Nasional Kimia XVIII, Yogyakarta, Indonesia, July $10^{\text {th }}, 2008$, Paper L0031-18.

[19] Y. Martha and A. Budiman, "Analisis suseptibilitas magnetik dan kandungan logam berat pada tanah lapisan atas di sekitar pabrik PT Semen Padang," J. Fis. Unand, vol. 7, no. 2, pp. 172-178, 2018, doi: 10.25077/jfu.7.2.172-178.2018.

[20] Y. Yusuf, U. Lukman, and F. Rahmi, "Analisis sedimen sekitar keramba jaring apung di perairan Danau Maninjau terhadap kandungan logam berat $\mathrm{Fe}, \mathrm{Cu}, \mathrm{Pb}$ dan $\mathrm{Cd}$," J. Ris. Kim., vol. 5, no. 1, pp. 94-100, 2015, doi: 10.25077/jrk.v5i1.191.

[21] R. Rasidi, E. Erlania, and A. B. Prasetio, "Evaluasi dan status perkembangan usaha budidaya ikan dalam keramba jaring apung di Danau Maninjau, Sumatera Barat," Media Akuakultur, vol. 5, no. 1, pp. 51-56, 2010, doi: 10.15578/ma.5.1.2010.51-56.

[22] P. Brouwer, Theory of XRF: Getting Acquinted with The Principles. Almelo, Netherlands: PANalytical, 2010. 
[23] M. E. Finnegan et al., "Synchrotron XRF imaging of Alzheimer's disease basal ganglia reveals linear dependence of high-field magnetic resonance microscopy on tissue iron concentration," $J$. Neurosci. Methods, vol. 319, pp. 28-39, 2019, doi: 10.1016/j.jneumeth.2019.03.002.

[24] F. Norman, A. Budiman, and D. Puryanti, "Hubungan ukuran butir terhadap suseptibilitas magnetik dan kandungan unsur mineral magnetik pasir besi Pantai Sunur Kabupaten Padang Pariaman," J. Fis. Unand, vol. 5, no. 3, pp. 238-243, 2016, doi: 10.25077/jfu.5.3.238-243.2016.

[25] N. G. D. Rusli, Hamdi, and F. Mufit, "Relatioship between basic composition of magnetic mineral and magnetic suseptibility value of guano from Bau Bau Cave East Kalimantan," Pillar Phys., vol. 4, pp. 49-56, 2014, doi: 10.24036/1843171074.

[26] H. Rifai, R. Putra, M. R. Fadila, E. Erni, and C. M. Wurster, "Magnetic susceptibility and heavy metals in guano from South Sulawesi caves," in IOP Conf. Ser. Mater. Sci. Eng., vol. 335, no. 1, p. 012001, 2018, doi: 10.1088/1757-899X/335/1/012001.

[27] B. Ramdani and A. Budiman, "Penentuan nilai suseptibilitas magnetik guano yang berasal dari Gua Baba Kecamatan Lubuk Kilangan Kota Padang," J. Fis. Unand, vol. 4, no. 1, pp. 97-102, 2015.

[28] I. Hardjono, Vulkanologi dan Mineralogi Petrografi. Surakarta, Indonesia: Muhammadiyah University Press, 2015.

[29] S. J. Hapsari, R. Latifah, and M. Muhaimin, "The role of black tea and pineapple juice as negative oral contrasts on magnetic resonance cholangiopancreatography (MRCP) examination," $J$. Vocational Health Studies, vol. 2, no. 3, pp. 121-126, 2019, doi: 10.20473/jvhs.V2.I3.2019.121126.

[30] E. N. Widyasari, R. T. Tjahjanto, and M. M. Khunur, "Pengaruh laju alir udara pada ozonisasi dalam oksidasi emas," J. Ilm. Kim. Univ. Brawijaya, vol. 1, no. 2, pp. 220-226, 2014. 